\title{
Correlation of serum thyroid stimulating hormone with body mass index in healthy adults.
}

Bishow Raj Baral ${ }^{1}$, Manoj Koirala ${ }^{1}$, Buddhi Sagar Lamichhane ${ }^{1}$, Suresh Raj Paudel ${ }^{2}$, Laxman Banstola ${ }^{3}$, Anand Nepal ${ }^{4}$, Swasti Sharma

${ }^{1}$ Department of Internal Medicine, Pokhara Academy of Health Sciences, Western Regional Hospital

${ }^{2}$ Deparment of Surgery' Pokhara Academy of Health Sciences, Western Regional Hospital

${ }^{3}$ Deparment of Pathology, Pokhara Academy of Health Sciences, Western Regional Hospital

${ }^{4}$ Department of Dermatology and Venereal diseases, Pokhara Academy of Health Sciences, Western Regional Hospital

${ }^{5}$ Department of ENT-HNS, Pokhara Academy of Health Sciences, Western Regional Hospital

\section{Correspondence:}

Dr. Bishow Raj Baral, MD,

Pokhara Academy of Health Sciences,

Western Regional Hospital, Pokhara, Nepal

Email: bishowrajbaral@yahoo.com

Article received : $26^{\text {th }}$ March 2018

Article accepted : $8^{\text {th }}$ Feb. 2019

\section{ABSTRACT}

Background: Obesity, a chronic disease that is increasing in prevalence in adults, adolescents and children, is now considered a global epidemic. Thyroid dysfunction contributes to the pathogenesis of obesity. Many clinical studies raise the questions of whether thyroid-stimulating hormone (TSH) changes in physiological limits is associated with obesity and whether there is a link between adipose tissue and hypothalamo-thyroidal axis. Materials and Method: This was a cross-sectional study. All clinically euthyroid patients and healthy volunteer adults of age 18 to 60 years of either gender were included in the study. Fasting blood sample was taken for thyroid function evaluation, which included Free T 3, Free T4 and thyroid stimulating hormone. Height, weight, waist circumference and hip circumference were measured. The results were compared with calculated Body Mass Index (BMI).

Results: 61patients who met the inclusion criteria were studied. Among 61 patients 16 had subclinical hypothyroidism, 2 patients had hypothyroidism and 43 were euthyroid. Similarly, 2 underweight patients were observed, 7 had normal weight, 13 were over weight and 39 were obese .The mean TSH according to BMI were 3.8, $4.04,3.88$ and 6.19 respectively. Conclusion: The result in this study showed that the mean TSH increased as BMI increased with significant relationship between serum TSH and BMI ( $\mathrm{p}<0.001)$. Thus thyroid dysfunction mainly subclinical hypothyroidism and hypothyroidism could be found in association with increased body weight .

Keywords: Thyroid Stimulating Hormone, Body Mass Index, Free T 3, Free T4, 
Thyroid dysfunction is one of major public health issues among the Nepalese population. It has been estimated that endocrine disorders is responsible for $0.2 \%$ of the deaths in Nepal, major cause is due to Iodinedeficiency ${ }^{1}$. According to WHO more than 190 million suffer from Iodine deficiencydisorder ${ }^{2}$.

Obesity is an abnormal accumulation of adipose tissue mass in body. Although viewed as similar to increased body weight, this always need not be the case-lean but very muscular people may be overweight by numerical standards without having excess adiposity ${ }^{3}$. Therefore Obesity is more effectively explained by assessing its linkage to morbidity or mortality. Though not a direct measuring system of adiposity, the most widely used method to gauge obesity is the body mass index (BMI), which is equal to weight $/$ height $^{2}\left(\mathrm{in} \mathrm{kg} / \mathrm{m}^{2}\right)$. Based on data of substantial morbidity, a BMI of 25 is mostcommonly used as a threshold for obesity in both men and women. For Asians, overweight is a BMI between 23 and $24.9 \mathrm{~kg} /$ $\mathrm{m} 2$ and obesity a BMI $>25 \mathrm{~kg} / \mathrm{m} 2^{4}$.

The Nepal Non-Communicable Diseases Risk Factor Survey, which included 15 of 75 districts and represented all five administrative regions and three ecological regions, estimated the prevalence of overweight at about $7 \%$ and the prevalence of obesity at around $1.7 \% 5$

Relationship between thyroid profile and body mass measures including body mass index (BMI) has previously been studied but not well understood. Most recent studies focusing on this relationship have conflicting results. Even small changes in TSH levels can have an effect on BMI profile. There exists a significant positive association between TSH and BMI in euthyroid subjects. $^{6}$

\section{MATERIALS AND METHOD}

It was a, Cross-sectional, prospective, hospital based observational study. Patients admitted in medical ward or OPD of Bir Hospital or Shree Birendra Hospital were evaluated from 2013 May to 2016 May. Sixty-one patients were included in the study. Subjects admitted and attending outpatient department in hospital during study period were included in the study after obtaining informed consent.

\section{Inclusion criteria}

- All clinically Euthyroid Adults age (18-60years)

\section{Exclusion criteria}

- Subjects with thyroid diseases, nodules and cancer,

- Subjects not willing to give consent,

- chronic kidney diseases,

- chronic liver diseases, pregnancy, drugs alternating TSH levels

Data were collected using a structured proforma covering the relevant details. Subject fulfilling the inclusion criteria were explained about the nature of the study and informed written consent were obtained from those willing to get enrolled. , Body weight (kg) and height $(\mathrm{cm})$ were measured while subjects wear light clothing and no shoes.BMI was calculated as weight divided by squared height $(\mathrm{kg} / \mathrm{m} 2)$.Hip circumference was measured around the widest portion of buttocks. Waist circumference wasmeasured at the level of the umbilicus. The fasting (12 hours) sample of blood was sent for serum Thyroid function test analysis.

Statistical analysis was done using Microsoft Excel software and SPSS-21. Result obtained from the study was discussed with reference to current world literature. For the purpose of this study a $95 \%$ confidence interval was accepted and a p value $<0.05$ was taken as significant.

\section{RESULTS}

Table 1: Distribution of gender of respondents

\begin{tabular}{|c|c|c|}
\hline Gender & Frequency & Percent \\
\hline Male & 26 & 42.6 \\
\hline Female & 35 & 57.4 \\
\hline Total & 61 & 100 \\
\hline
\end{tabular}

Among the study population, 42.6 percent were male and 57.4 percent were female.

\section{Table 2: Distribution of age of respondents}

\begin{tabular}{|c|c|c|}
\hline Age & Frequency & Percent \\
\hline $21-30$ & 22 & 36.1 \\
\hline $31-40$ & 14 & 23.0 \\
\hline $41-50$ & 19 & 31.1 \\
\hline $51-60$ & 4 & 6.6 \\
\hline 61 and above & 2 & 3.3 \\
\hline Total & 61 & 100 \\
\hline
\end{tabular}



$\mathrm{TSH}=-15.99+0.817 \mathrm{BMI}$

The age distribution was as follows; $22(36.1 \%), 14$ (23.0\%), 19(31.1\%), 4 (6.6\%), and2 (3.3\%) in the $21-$ $30,31-40,41-50,51-60,>61$ age grown respectively. As the shown in the above graph most patients were in the $21-30$ age group and the minimum age was 21 and the maximum age 62 was with a mean of 37.7 and standard deviation of 11.9

\section{Table 3: Serum TSH and BMI}

\begin{tabular}{|c|c|c|c|c|c|}
\hline \multirow{2}{*}{ BMI } & \multicolumn{4}{|c|}{ TSH } & Frequency \\
\cline { 2 - 6 } & $\begin{array}{c}\text { Mini- } \\
\text { mum }\end{array}$ & $\begin{array}{c}\text { Maxi- } \\
\text { mum }\end{array}$ & Mean & SD & N \\
\hline $\begin{array}{c}\text { Under weight } \\
\left(<18 \mathrm{~kg} / \mathrm{m}^{2}\right)\end{array}$ & 3.1 & 4.5 & 3.8 & 0.98 & 2 \\
\hline $\begin{array}{c}\text { Normal } \\
\left(18-22.9 \mathrm{~kg} / \mathrm{m}^{2}\right)\end{array}$ & 1.6 & 12.5 & 4.04 & 3.87 & 7 \\
\hline $\begin{array}{c}\text { Overweight } \\
\left(23-24.9 \mathrm{~kg} / \mathrm{m}^{2}\right)\end{array}$ & 0.5 & 7.4 & 3.88 & 1.88 & 13 \\
\hline $\begin{array}{c}\text { Obese } \\
\left(>25 \mathrm{~kg} / \mathrm{m}^{2}\right)\end{array}$ & 0.8 & 50.5 & 6.19 & 7.71 & 39 \\
\hline
\end{tabular}

Table 4a: To identify the association between the level of TSH and BMI.

\section{ANOVA $^{b}$}

\begin{tabular}{|c|c|c|c|c|c|c|}
\hline \multicolumn{2}{|c|}{ Model } & $\begin{array}{c}\text { Sum of } \\
\text { Squares }\end{array}$ & Df & $\begin{array}{c}\text { Mean } \\
\text { Square }\end{array}$ & F & Sig. \\
\hline \multirow{2}{*}{1} & $\begin{array}{c}\text { Regression } \\
\text { Residual }\end{array}$ & 533.110 & 1 & 533.110 & 16.279 & $.001^{\mathrm{a}}$ \\
& $\begin{array}{c}1932.149 \\
\text { Total }\end{array}$ & 59 & 32.748 & & \\
& 2465.259 & 60 & & & \\
\hline
\end{tabular}

b. Dependent Variable: TSH

a. Predictors: (Constant), BMI

\section{Table 4b: Coefficients ${ }^{a}$}

\begin{tabular}{|c|c|c|c|c|c|}
\hline \multirow{2}{*}{} & \multicolumn{2}{|c|}{$\begin{array}{c}\text { Unstandardized } \\
\text { Coefficients }\end{array}$} & $\begin{array}{c}\text { Standardized } \\
\text { Coefficients }\end{array}$ & \multirow{2}{*}{ t } & \multirow{2}{*}{ Sig. } \\
\cline { 2 - 4 } & $\mathbf{B}$ & $\begin{array}{c}\text { Std. } \\
\text { Error }\end{array}$ & Beta & & \\
\hline \multirow{2}{*}{$\begin{array}{c}\text { (Constant) } \\
\text { BMI }\end{array}$} & -15.993 & 5.345 & & -2.992 & .004 \\
\cline { 2 - 4 } & .817 & .203 & .465 & 4.035 & .001 \\
\hline
\end{tabular}

\section{a. Dependent Variable: TSH}

\section{Regression Model}

As value of $\mathrm{R}^{2}$ is 0.216 , we can conclude that BMI is responsible for increment of TSH by $21.6 \%$. One unit of increment in BMI increases 0.817 of TSH. As p-value (0.001) is less than level of significance alpha (0.05), there is significant association between level of TSH and BMI.

\section{DISCUSSION}

Obesity and its consequences is one of the big problems in developed countries

and now it is also growing in developing countries .However, it depends on geographical ,cultural, social land ethnical factor. It also vary from nations to nations, and in some country like Nepal with various diversity it can be influence by multifactorial cause, with significant morbidity and mortality. The lipid profile is found to be altered in thyroid dysfunction. Dyslipidemia causing obesity is one of the modifiable risk factor for cardiovascular disease.

Among the 61 patients evaluated in this study, 35 (57.4\%) were females and the remaining 26 (42.6\%) were males. In general, the gender distribution among the patients has a geographical, social and cultural variation. However, female preponderance is seen in this study.

Female gender 23 (65.7\%) were euthyroid,10 (28.6\%) were subclinical hypothyroid, 2(5.7\%) were hypothyroid and male 20(76.9\%) were euthyroid, 6 (23.1\%) were subclinical hypothyroid and nil were hypothyroid. . In this study female patient (19.6\%) were suffering from thyroid dysfunction which is more than male $(9.8 \%)$ out of total $(29.5 \%)$ of overall thyroid dysfunction.

Most patients were in the age group 21-30 years age group and the minimum age was 21 years and the maximum age 62 years with a mean of 37.7 and standard deviation of $11.9+/-2$. Patient with increasing age group was found to be increased TSH level.

Holowell et al. found that subclinical thyroid disorder was found to be higher in the age group 40-60 years ${ }^{7}$.

A Regmi etal. in their study found overall thyroid dysfunction was detected in $25.7 \%$ of the study population with the higher prevalence among females ${ }^{8}$. Similarly In study done by Raj kumar yadav et al found the prevalence of thyroid dysfunction $17.42 \%$. Females had more thyroid dysfunction than the males. Hypothyroidism 
$(2.26 \%)$ and subclinical hypothyroidism $(10.50 \%)$ had higher prevalence compared to hyperthyroidism (1.59\%) and subclinical hyperthyroidism (3.05\%) in the western region of Nepal. ${ }^{9}$

These study are consistent with this study .However, a different result was observed by Baral $\mathrm{N}$ et al, where they reported equal prevalence of thyroid dysfunction in males and females. ${ }^{10}$

Patients in the study presented with nonspecific symptoms and the most common presenting symptom was Fatigability, which was found in 27(44.3\%) patients. This was followed by the anxiety, weight gain, edema, dyspnea cold intolerance and heat intolerance which was found in $10(16.4 \%), 10(16.4 \%), 9$ (14.8\%), 7 (11.5\%) , and $5(8.2 \%)$ of the patients respectively.

Trivalle $\mathrm{C}$ et al. study found the clinical features of thyroid disorders tend to be nonspecific and fewer in elderly compared to younger patients and the symptoms are often confused with normal ageing process and coexisting diseases ${ }^{11}$.This may sometime can cause greater number of elderly patients being undiagnosed.

In this study, BMI of Underweight $(<18 \mathrm{~kg} / \mathrm{m} 2)$ had Mean TSH level 3.8 and standard deviation of 0.98 ,for Normal $(18-22.9 \mathrm{~kg} / \mathrm{m} 2)$ had Mean TSH level of 4.04 and standard deviation of 3.87.in Overweight(23-24.9 $\mathrm{kg} / \mathrm{m} 2$ ) had Mean TSH level of 3.88 and standard deviation of 1.88 Obese $(>25 \mathrm{~kg} / \mathrm{m} 2))$ had Mean TSH level of 6.19 and standard deviation of 7.71. As value of $\mathrm{R}^{2}$ is 0.216 , we can conclude that BMI is responsible for increment of TSH by $21.6 \%$. One unit of increment in BMI increases 0.817 of TSH. As p-value (0.001) is less than level of significance alpha $(0.05)$, there is significant association between level of TSH and BMI.

The above finding revealed that with increasing the TSH level there is significantly increasing trend of BMI. The finding is similar as compared to other study, and this study also revealed that obesity is related with TSH level however cannot conclude that obesity is due to hypothyroidism, since there are many confounders.

Several studies suggest that the association between serum TSH and body weight may be influenced by hormonal signals from adipose tissue such as leptin ${ }^{12}$. Our study did not measure leptin or any of the other putative adipokines to determine if varying concentrations of these hormones affected regulation of thyroid hormones.
A study done in India by Amrita Solanki et al.bout the relationship between different BMI groups and serum TSH found as the BMI increased mean value of serum TSH also increased. The plausibility of association between TSH and BMI could be due to TSHdirectly stimulating preadipocyte differentiation and, resulting in adipogenesis ${ }^{13}$.Knudsen et al., reported a positive association between BMI and serum TSH concentrations ( $\mathrm{P}<0.001)$ and also showed that thyroid function was correlated to increased weight over 5 years .Researchers found a higher odds ratio for obesity with serum TSH above $3.6 \mathrm{mU} / \mathrm{L}$, and a significant odds ratio of 2.1 was found when comparing serum TSH $>3.6 \mathrm{mU} / \mathrm{L}$ to serum TSH of $1.0-1.99 \mathrm{mU} / \mathrm{L} .{ }^{14}$ Svare et al., found that for each unit $(\mathrm{mU} / \mathrm{L})$ increase in TSH concentration among women, weight increased $0.9 \mathrm{~kg}$ and BMI increased 0.3 $\mathrm{kg} / \mathrm{m}^{2} .{ }^{15}$

\section{CONCLUSION}

As the present study was a hospital-based study, it may not represent the whole population. Significantly Positive correlation was observed between patients with high serum TSH and higher BMI (including both over weight and obese) than euthyroid subjects $(\mathrm{P}<0.001)$. The above finding revealed that obesity is related with TSH level however cannot conclude that obesity is due to hypothyroidism, since there are many confounders.

\section{REFERENCES}

1. Ganie MA., ZargarAH. Scenario of endocrinology in South Asia. Indian J Endocrinol Metabol 2007; 11: 1-2.

2. WHO/ICCIDD/UNICEF. Assessment of iodine deficiency disorders and monitoring their elimination. 2nd edition. Geneva: WHO. 2001.

3. Jeffrey S. Filer, Eleftheria Maratos-Filer. Biology of Obesity. In: Fausi AS, Braunwald E, Kasper DL, Hauser SL, Longo DL, Jameson JL et al editors. Harrison's Principle of Internal Medicine. $18^{\text {th }}$ Ed. New York: McGraw Hill; 622

4. WHO Expert Consultation: Appropriate body mass index for Asian Populations and its implications for Policy and intervention strategies. Lancet 2001; 363:157-63.

5. Nepal Non-Communicable Diseases Risk Factor 


\section{Survey}

6. A Nyrnes, R Jorde et al. Serum TSH is positively associated with BMI.International Journal of Obesity.2006;30:100-105

7. Hollowell JG, Staehing NW, Flanders WD et al. Serum TSH,T4, and thyroid antibodies in the United States Population(1988 to 1994): National Health and Nutrition Examination Survey (NHANES III). J Clin Endocrinol Metabol 2002; 87: 489-99.

8. A Regmi, B Shah, BR Rai, et al. Serum lipid profile in patients with thyroid disorders in central Nepal Nepal Med Coll J 2010;12(4): 253-256

9. Raj Kumar Yadav, Namrata Thapa Magar, Bibek Poudel, Naval Kishor Yadav, Binod Yadav et al.A Prevalence of Thyroid Disorder in Western Part of Nepa. Kathmandu Univ Med J (KUMJ). 2010 Apr-Jun;8(30):231-7

10. Baral N, Lamsal M, Koner BC, Koirala S. Thyroid dysfunction in eastern Nepal. South Asian J Trop Med Public Health 2002; 33: 638-41.

11. Trivalle C, Doucet J, Chasagne P et al. Difference in the signs and symptoms of hyperthyroidism in older and young patients. $J$ Amer Geriatric Society 1996; 44: 50-3.

12. Feldt-Rasmussen U. Thyroid and leptin. Thyroid 2007;17:413-9.

13. Amrita Solanki, Shaifali Bansal,and Uma Shankar Shukla et al. Relationship of serum thyroid stimulating hormone with body mass index in healthy adults. Indian J Endocrinol Metab. Oct 2013; 17: S167-S169

14. Knudsen N, Laurberg P, Rasmussen LB, Bulow I, Perrild H, Ovesen L, et al. Small differences in thyroid function may be important for body mass index and the occurrence of obesity in the population. J Clin Endocrinol Metab 2005;90:4019-24.

15. Svare A, Nilsen TIL, Bjøro T, Åsvold BO, Langhammer A. Serum TSH related tomeasures of bodymass: Longitudinal datafrom theHUNTstudy, Norway. ClinEndocrinol.2011;74(6):769-75. 